\title{
A SÚRLÓDÁSI TÉNYEZŐ PONTOS MEGHATÁROZÁSÁT BEFOLYÁSOLÓ KÖRÜLMÉNYEK VIZSGÁLATA GYƯRÜ ZÖMÍTÉSÉNÉL
}

\section{EXAMINATION OF THE BOUNDARY CONDITIONS IN DETERMINATION OF THE FRICTION COEFFICIENT BY RING UPSETTING}

\author{
Szerencsés Ádám ${ }^{1}$, Gonda Viktor ${ }^{2}$ \\ Óbudai Egyetem, BGK-AAT, 1081, Magyarország, Budapest, Népszínház utca 8;

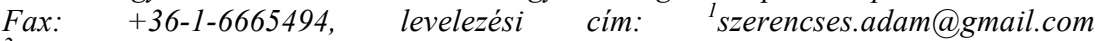 \\ '2gonda.viktor@bgk.uni-obuda.hu
}

\begin{abstract}
Ring upsetting is widely used for the determination of the friction coefficient. While the measurement is easy to carry out, many factors affect the accuracy of the results. In the present paper, we examine the effecting factors, and evaluate them by considering the error they introduce in the results. We carried out both finite element simulation and experiments on $\mathrm{Al}$ and $\mathrm{Cu}$ specimens with various boundary conditions.
\end{abstract}

Keywords: material testing, ring upsetting, measurement error, lubrication condition, friction coefficient.

\section{Összefoglalás}

A gyürủ geometriájú próbtest zömítése egy igen széleskörủen elterjedt módja a súrlódási mérőszámok meghatározásának. A vizsgálat egyszerüsége mellett azonban sok tényező befolyásolhatja a mérés kimenetelét. Jelen dolgozat ezeknek a tényezőknek a feltárására irányul, valamint rangsorolásukra az alapján, hogy milyen mértékben visznek hibát a kiértékelésbe. A kísérletet $\mathrm{Al}$ és $\mathrm{Cu}$ próbatestekkel különböző peremfeltételek mellett végeztük el, végeselemes modellel segítettük a kiértékelést.

Kulcsszavak: anyagvizsgálat, gyürüzömités, mérési hiba, kenési feltétel, súrlódási együttható.

\section{Bevezetés}

A képlékenyalakításnál a súrlódási viszonyok kiemelt fontossággal bírnak. A súrlódási mérőszámok meghatározására többféle vizsgálat létezik: a szalaghúzó próba, nyújtva hajlító próba, valamint a gyürüzömítő vizsgálat [1]. A gyürüzömítő vizsgálat egyszerủen végrehajtható, viszont eredményeinek jóságát befolyásolja, ha a súrlódó felületek eltérő felületi minőséggel rendelkeznek, és/vagy a kenés helyes kivitelezésében hibát vétünk. Ezen peremfeltételek hatását vizsgáljuk kísérleti úton és végeselemes szimuláció segítségével.

\section{Elméleti háttér}

\subsection{A gyűrưzömítő vizsgálat}

A súrlódási tényező meghatározására szolgáló gyakori vizsgálat a gyürü alakú darabok zömítő vizsgálata. Egy hengeres gyürüt két síklap között axiális irányban „h, "-ról „h” magasságra zömítve, a külső és 
belső átméröjének megváltozása a szerszámmal érintkező felületek között ébredő súrlódás nagyságától függ.

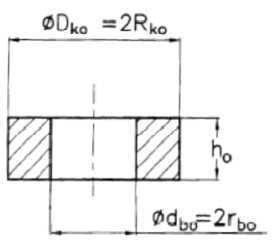

$a$,

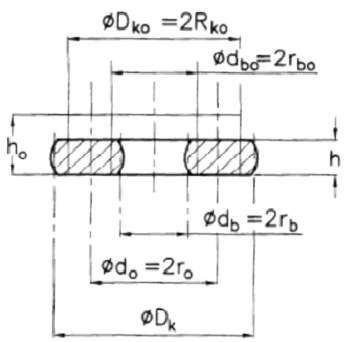

$c$,

1. ábra. A gyürü kiinduló (a,) és zömités utáni $(b, c$,) geometriája és méretei.

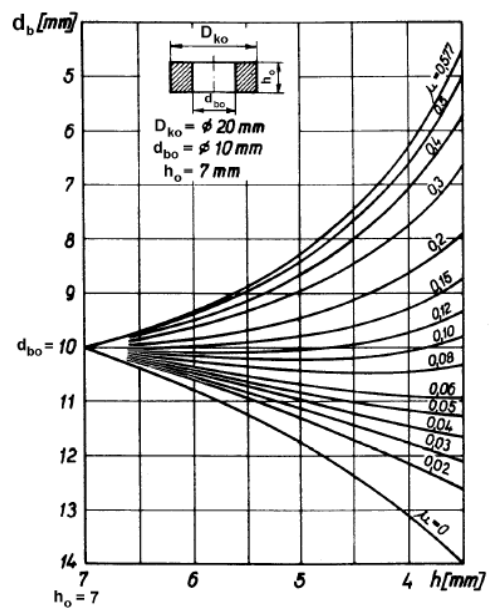

2. ábra. Burgdorf-nomogram

Ha a súrlódási tényező kicsi, akkor a gyürü belső átmérője gyakorlatilag nem változik, ellenben a külső átmérő jelentősen növekszik. Kedvezötlen súrlódási viszonyok mellett a külső átmérő kevésbé nő, a belső átmérő csökken. Tehát a „h” magasságra zömített gyürü geometriája hordozza a súrlódási viszonyokra vonatkozó információt.

\subsection{A zömítés utáni méretek}

A zömítés során a gyürủ külső és belső palástfelületei a súrlódás miatt hordósodnak. A próbatest zömítés elötti és utáni geometriája az 1. ábrán látható.

A „h” zömítési magassághoz tartozó idealizált (hordósodás nélküli állapothoz tartozó) geometriai méretek, valamint a semleges (helyben maradó) réteg helyzete a térfogat állandóság felhasználásával határozható meg az alábbi képletek felhasználásával az 1. ábra geometriai jelöléseivel. Az idealizált külső átmérő, $\mathrm{D}_{\mathrm{k}}$ :

$$
D_{k}=\frac{2 \cdot D^{\prime \prime}+D^{\prime}}{3}
$$

Az idealizált belső sugár, $\mathrm{r}_{\mathrm{b}}$ :

$$
r_{b}=\sqrt{R_{k}^{2}-\left(R_{k 0}^{2}-r_{b 0}^{2}\right) \frac{h_{0}}{h}}
$$

A semleges réteg sugara, $\mathrm{r}_{0}$ :

$$
r_{0}=\sqrt{\frac{R_{k 0}^{2} \cdot h_{0}-R_{k}^{2} \cdot h}{h_{0}-h}}
$$

\subsection{A súrlódási mérőszámok megha- tározása}

A gyürü feszültség- és alakváltozás analízise alapján határozhatók meg a súrlódási jellemzők [1]. Zárt alakban csak a Kudo-féle súrlódási szám számítására vonatkozó képlet írható fel, Coulomb-féle súrlódási tényező, $\mu$, csak numerikus integrálás segítségével számítható. A mért geometriai méretekből a $\mu$ súrlódási tényező egyszerü és gyors meghatározását teszi lehetővé a Burgdorf-nomogram, amely a 2. ábrán látható, adott kiinduló méretekkel rendelkező gyürü zömítése során alkalmazható. 


\section{A kísérlet leírása}

\subsection{A kísérlet célja}

Vizsgálatunk célja, hogy megállapítsuk, hogyan befolyásolja a gyürüzömítö vizsgálat eredményét, ha a próbatest felületein eltérnek a súrlódási viszonyok.

\subsection{A vizsgált paraméterek}

Próbatest anyagminősége:

Alumínium (Al) és Réz (Cu).

A keményfém nyomólap felülete:

Sima, érdes.

Az alkalmazott kenőanyag:

Molibdén-diszulfid $\left(\mathrm{MoS}_{2}\right)$ és

Molykote (1. táblázat).

\subsection{A mérés menete}

A zömítést mind a két felsorolt anyagminőségnél elvégeztük különböző kenési feltételek mellett. Az első mérés során, hagyományos módon, a gyürü mindkét felületét kentük. Ezek lesznek az összehasonlítások alapjai. A második mérésnél csak az egyik oldalt kentük, így annak sima, a másik oldalnak pedig kenőanyagmentes, érdes felületet biztosítottunk. Az alumínium gyürüknél két különböző kenőanyaggal is végrehajtottuk a kísérletet a második esetre vonatkozóan. Összesen 7 mérési esetet határoztunk meg (1. táblázat: 1-7. sorszám).

\section{Végeselemes szimuláció}

A végeselem analízis során a réz próbatestek 6. és 7. sorszámú zömítését modelleztük. Tengelyszimmetrikus síkbeli modellt hoztunk létre. A próbatestet rugalmasképlékeny keményedő anyag-modellel, a szerszámokat merev testként modelleztük. Súrlódási modellre a Coulomb-féle modellt alkalmaztuk, a súrlódási együttható értékei: a sima, kent felületen $\mu_{\text {felsón }}=0,04$, az érdes felületen $\mu_{\text {alsó }}=0,5$. A szimulációból kapott eredmények 8. (6. alapján) és 9. (7. alapján) sorszámot kapták az 1. táblázatban. A deformált gyürü az 1.b ábrán definiált geometriai adatait kiolvastuk a programból, ezek a mért értékek oszlopokban szerepelnek.

$\mathrm{Az}$ 3. ábrán a 8-as számú eset szimulációs eredménye látható. Megfigyelhetjük a gyürủ keresztmetszetében a geometria torzulását. Az ábra szürkeárnyalatai az összehasonlító alakváltozás értékeit jelölik, az értékek 0 és 1,8 között alakulnak, a világosabbtól a sötét színek felé növekednek.

A felső felülethez közeli anyagrész a kis súrlódás miatt x-irányában (a 3. ábrán jobbra) mozdul el, belső átmérő növekszik. $\mathrm{Az}$ alsó, érdes felületen a nagy súrlódás miatt gátolt az anyagrészek elmozdulása, a palástfelülethez közeli anyag fordul rá a nyomólapra, helyileg a belső átmérő növekedését okozva. A zömítettség növekedésével a gátolt elmozdulású anyagrészek hatása lesz a meghatározó, így a belső átmérő csökken.

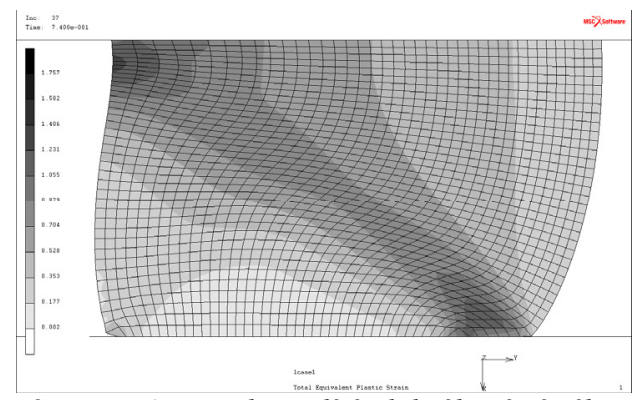

3. ábra. Az összehasonlitó alakváltozás értékei

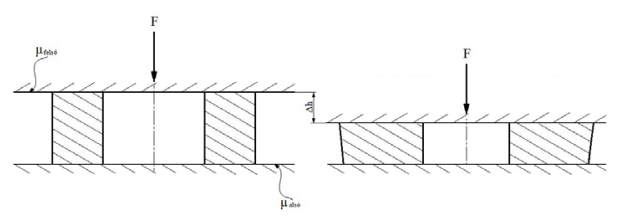

4. ábra. Kúposság a kedvezőtlen kenésnél

\section{Eredmények}

Megfigyelhető, hogy ha a próbatest felületein eltérö a súrlódás, akkor a zömített darabok nem hordósodnak, hanem kúpos alakot vesznek fel (4. ábra). Ez annak tudható be, hogy a különböző felületeken 
eltérő nagyságú a súrlódási együttható értéke, azaz zömítés közben a radiálisan elmozduló anyagrészek fékezettsége az érdesebb nyomólapon nagyobb.

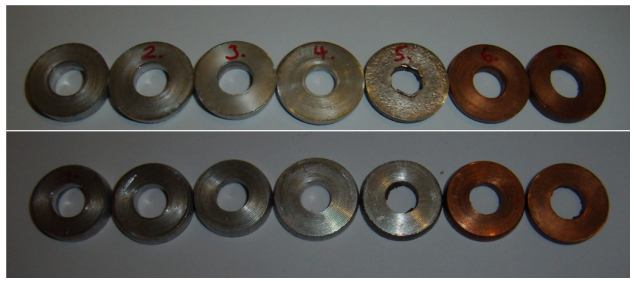

5. ábra. A zömített darabok felül-és alulnézete

1. táblázat. A kisérlet eredményei

\begin{tabular}{|c|c|c|c|c|c|c|c|c|c|c|c|c|}
\hline \multirow[b]{2}{*}{$\begin{array}{l}\text { Sor- } \\
\text { szám }\end{array}$} & \multirow[b]{2}{*}{$\begin{array}{c}\text { Anyagmi- } \\
\text { nôség }\end{array}$} & \multirow[b]{2}{*}{ Kenés } & \multicolumn{4}{|c|}{ Mért értékek } & \multicolumn{4}{|c|}{ Számitott értékek } & \multicolumn{2}{|c|}{$\begin{array}{c}\text { Nomogramról } \\
\text { leolvasott értékek }\end{array}$} \\
\hline & & & $\left.\begin{array}{c}H \\
{[\mathrm{~mm}]}\end{array}\right]$ & $\begin{array}{c}D^{\prime} \\
{[\mathrm{mm}]}\end{array}$ & $\begin{array}{c}D^{\prime \prime} \\
{[\mathrm{mm}]}\end{array}$ & $\begin{array}{c}d_{0} \\
{[\mathrm{~mm}]}\end{array} \mid$ & $\left.\begin{array}{c}D_{k} \\
{[\mathrm{~mm}]}\end{array}\right]$ & $\begin{array}{c}r_{0} \\
{[\mathrm{~mm}]}\end{array}$ & $\left.\begin{array}{c}r_{0} \\
{[\mathrm{~mm}]}\end{array}\right]$ & $\begin{array}{l}m \\
{[-]}\end{array}$ & $\begin{array}{c}\mu[-] \\
\left(d_{0} \text { mért }\right. \\
\text { értékhez } \\
\text { tortozó) }\end{array}$ & $\begin{array}{c}\mu[-] \\
\left(d_{b}=2^{\circ} r_{0}\right. \\
\text { számitott } \\
\text { értékhez } \\
\text { tartozó) }\end{array}$ \\
\hline 1. & Al & \multirow{2}{*}{$\begin{array}{c}\text { Mindkét oldal } \\
\text { kent }\left(\mathrm{MoS}_{2}\right)\end{array}$} & 5,2 & 22,7 & 23,15 & 10,03 & 23,00 & 5,59 & 2,61 & 0,0210 & 0,12 & 0,04 \\
\hline 2. & Al & & 4,6 & 23,71 & 24,48 & 10,02 & 24,22 & 5,71 & |3,24 & 0,0292 & 0,12 & 0,03 \\
\hline 3. & Al & \multirow{2}{*}{\begin{tabular}{|c|}
$\begin{array}{c}\text { Felsố oldal kent } \\
\text { (MoS2), alsó } \\
\text { érdes }\end{array}$ \\
\end{tabular}} & 5,3 & 22 & 23,13 & 9,78 & 22,75 & 5,51 & 2,87 & 0,0284 & 0,16 & 0,02 \\
\hline 4. & Al & & 4,05 & 24,34 & 25,23 & 8,66 & 24,93 & 5,08 & 4,89 & 0,1106 & 0,2 & 0,1 \\
\hline 5. & Al & \begin{tabular}{|c|}
$\begin{array}{c}\text { Felsỗ oldal kent } \\
\text { (Molykote), alsó } \\
\text { érdes }\end{array}$ \\
\end{tabular} & 4,35 & 23,26 & 24,49 & 9,05 & 24,08 & 4,93 & 5,12 & 0,1565 & 0,2 & 0,13 \\
\hline 6. & Cu & \begin{tabular}{|c|}
$\begin{array}{c}\text { Felsỗ oldal kent } \\
\text { (Molykote), alsó } \\
\text { érdes }\end{array}$ \\
\end{tabular} & 4,4 & 23,23 & 24,5 & 9,44 & 24,08 & 5,06 & |4,90 & $0,1271 \mid$ & 0,16 & 0,13 \\
\hline 7. & Cu & \begin{tabular}{|c|} 
Mindkét oldal \\
kent (Molykote)
\end{tabular} & 4,45 & 24,23 & 24,55 & 10,56 & 24,44 & 5,60 & 3,72 & 0,0425 & 0,08 & 0,04 \\
\hline 8. & $\mathrm{Cu}$ & \begin{tabular}{c|} 
Szimuláció, \\
felső oldal jól \\
kent $(\mu=0,04)$, \\
alsó érdes \\
$(\mu=0,5)$
\end{tabular} & 4,41 & 22,26 & 24,35 & 9,32 & 23,65 & 4,56 & 5,67 & $0,294 \mid$ & 0,19 & 0,2 \\
\hline 9. & $\mathrm{Cu}$ & \begin{tabular}{|c|} 
Szimuláció, \\
mindkét oldal \\
jól kent $(\mu=0,04)$
\end{tabular} & 4,48 & 24,36 & 24,57 & 11,38 & 24,5 & 5,74 & 3,31 & $\mid 0,029$ & 0,03 & 0,03 \\
\hline
\end{tabular}

A belső átmérők alakulása szabad szemmel is jól látható a súrlódási értékek függvényében (5. ábra). $\mathrm{Az} 1$. , 2. és 7. számú gyürünél megfigyelhető, hogy a belső átmérő nem-, vagy csak kis mértékben nőtt, a többi darabnál viszont csökkent. Ebből előre becsülhető, hogy a felsorolt gyürüknél a súrlódási együttható kis értéket vett fel, a többinél pedig nagyobb értékekre számíthatunk.

A kísérletek és a szimulációk eredményei összesítve az 1. táblázatban láthatók.

\section{Az eredmények értékelése, kö- vetkeztetések}

$\mathrm{Az}$ idealizált kenési feltételekhez meghatározott képleteket használva a mind a két kenési esetre, a réznél azt tapasztaljuk, hogy a súrlódási együtthatók számított és mért értékből kapott eredmények között minimális az eltérés. Az alumínium próbatestek egyenetlen alakváltozása miatt a két érték között többnyire egy nagyságrenddel kisebb lett a számított értékhez tartozó súrlódási együttható.

$\mathrm{Az}$ alumíniumnál kipróbált kétféle kenőanyag közel ugyanazt a súrlódási együttható értéket adta.

A megfelelö, kétoldali kenés biztosításával a súrlódási együttható közel a harmadára csökkent az "elrontott" kenési állapothoz képest.

A rossz kenési viszonyok ingadozó, eltérö, hibás értékeket adnak. Ezt jól látni az alumínium 3. számú gyürü zömítésénél, ahol a vele azonos körülmények között zömített 4. számú gyürütől nagyértékben eltérő eredményeket kaptunk. Összevetve a jól kent 1. számú gyürü adataival, irreális, ellentmondásos értéket kapunk, mivel a kapott súrlódási együtthatóra kisebb érték adódott, amikor annak nagyobbnak kellett volna lennie az érdes felület miatt.

Összehasonlítva a kiértékelt súrlódási együttható értékeit azonos és eltérő súrlódási viszonyok mellett réz próbatest és Molycote kenőanyag használatakor (6. és 7. eset) a „rossz kenés” extrém esetén meghatározott 0,13 -as érték több mint $3 x$ nagyobb a jó 0,04-es értékhez képest. Ez a legrosszabb esetet jelenti, tehát legnagyobb eltérés 0,1 tekinthető a hiba felső határának.

\section{Szakirodalmi hivatkozás}

[1] dr. Horváth László: Képlékenyalakitás alapfogalmai. Elektronikus jegyzet, Óbudai Egyetem, 2003, 30-35. oldal. 